\title{
The "floating ulna" injury in adults: a case report, literature review and proposed injury classification
}

Tian $\mathrm{He}^{1,2}$, Xin Wang ${ }^{2}$, Shui Sun ${ }^{1 *}$ and Lugang Zhou ${ }^{2 *}$

\begin{abstract}
Background: Ipsilateral Galeazzi fracture with elbow dislocation, namely the "floating ulna" injury, is a rare injury pattern. A few reports have described this type of injury and its treatment.

Case presentation: A 33-year-old female at $38^{+}$weeks gestational age presented with Galeazzi fracture and posterolateral elbow dislocation of the left upper extremity. The patient was treated with closed reduction of the elbow, open reduction, and internal fixation of the radial shaft fracture with a dynamic compression plate and Kwire stabilization of the unstable distal radioulnar joint. At the 12-month follow-up, the patient had no pain or signs of instability. Range of motion was $0-135^{\circ}$ at the elbow, $70^{\circ}$ extension and $80^{\circ}$ flexion at the wrist, and $80^{\circ}$ supination and $80^{\circ}$ pronation at the forearm.

Conclusion: The "floating ulna" injury is a rare and special injury pattern with ipsilateral Galeazzi fracture and elbow dislocation. This type of injury was likely caused by significant amount of deforming force and the unique position of upper limb when the patient fell from a height of 1-2 $m$ in high-energy trauma.
\end{abstract}

Keywords: Galeazzi fracture, Elbow joint dislocation, Floating ulna, Injury classification

\section{Background}

The Galeazzi fracture dislocation occurs in $6.8 \%$ of all adult diaphyseal forearm fractures [1,2]. The elbow dislocation accounts for $11-28 \%$ of all injuries to the elbow [3]. Only a few cases have reported Galeazzi fracture combined with ipsilateral elbow dislocation [4-10]. The present report describes a rare case of the combination of Galeazzi fracture and dislocation of the left elbow. The mechanism, injury factors, injury classification, and treatment are discussed with a review of the literature.

\footnotetext{
* Correspondence: hunterhe@hotmail.com; hetian000@126.com ${ }^{1}$ Department of joint surgery, Shandong Provincial Hospital, Cheeloo College of Medicine, Shandong University, 324 Jingwuweiqi Road, Huaiyin, Jinan, Shandong 250021, P. R. China

${ }^{2}$ Department of Orthopedics Surgery, Yantai Yuhuangding Hospital Affiliated to Medical College of Qingdao University, 20 East Yuhuangding Rd, Zhifu District, Yantai 264400, Shandong, P. R. China
}

\section{Case presentation}

A 33-year-old female at $38^{+}$weeks gestational age presented to the emergency room with left forearm and brain injury, which she sustained after falling off her motorbike in a motorbike accident. She stated that she had fallen on the outstretched left arm. Clinical examination revealed deformity of the elbow and forearm. Bilateral extremities were deformed and swollen obviously. No neurovascular injury was present. Despite a normal prenatal ultrasound and computerized tomography (CT) scan of the brain, X-ray of the forearm showed a transverse fracture of the radial shaft at the junction of the middle and distal thirds, dorsal dislocation of the ulnar head and posterolateral dislocation of the elbow (Fig. 1).

The patient was taken to the operating room three hours after arrival at the emergency department. Under brachial plexus nerve block, reduction of the elbow dislocation was performed immediately, and radiographs

(c) The Author(s). 2021 Open Access This article is licensed under a Creative Commons Attribution 4.0 International License, which permits use, sharing, adaptation, distribution and reproduction in any medium or format, as long as you give appropriate credit to the original author(s) and the source, provide a link to the Creative Commons licence, and indicate if changes were made. The images or other third party material in this article are included in the article's Creative Commons licence, unless indicated otherwise in a credit line to the material. If material is not included in the article's Creative Commons licence and your intended use is not permitted by statutory regulation or exceeds the permitted use, you will need to obtain permission directly from the copyright holder. To view a copy of this licence, visit http://creativecommons.org/licenses/by/4.0/ The Creative Commons Public Domain Dedication waiver (http://creativecommons.org/publicdomain/zero/1.0/) applies to the data made available in this article, unless otherwise stated in a credit line to the data. 


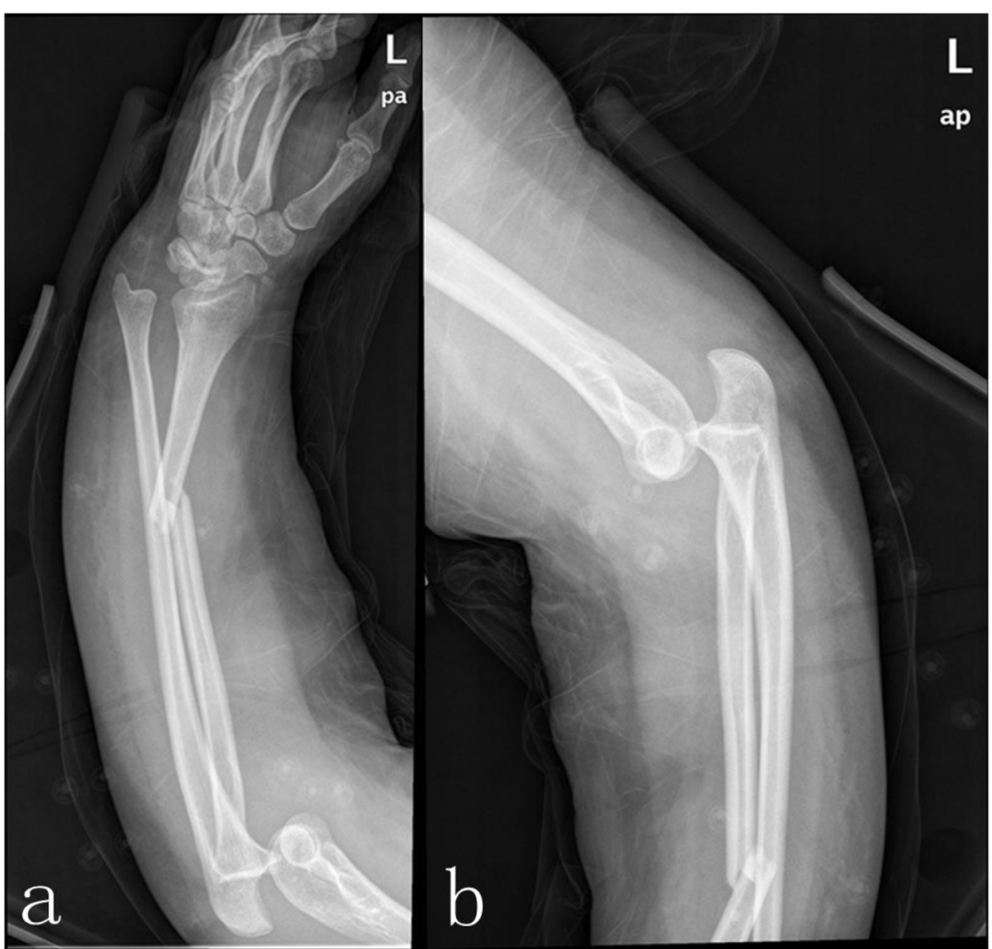

Fig. 1 X-ray of the left forearm showing both Galeazzi fracture and elbow dislocation. The fracture of radial shaft at the junction of middle and distal thirds, dorsal dislocation of the ulnar head (a), posterolateral dislocation of the elbow(b)

confirmed the elbow to be in joint and tested stability. After that, the patient underwent an open reduction and internal fixation of the radial fracture using a standard palmar approach of Henry [11]. A seven-hole 3.5-mm locking compression plate was used to stabilize the radius. Although the dislocation of the distal radioulnar joint (DRUJ) was anatomically reduced after internal fixation, when the forearm was pronated, dorsal dislocation of the ulna was found under fluoroscopic examination and pinned in neutral position using a $2.0-\mathrm{mm}$ Kirchner

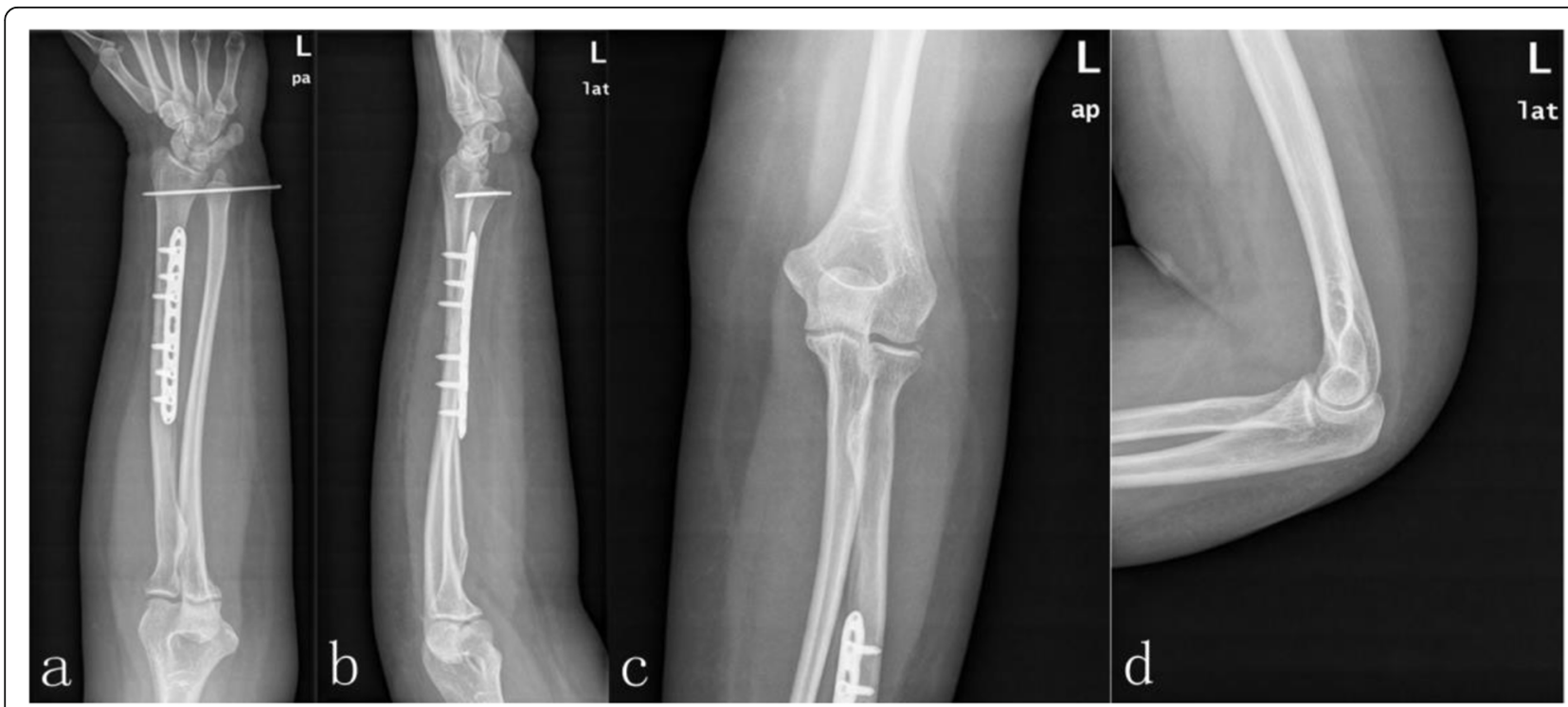

Fig. 2 Postoperative radiographs of the left forearm and elbow show successful reduction and fixation of both Galeazzi fracture and elbow dislocation: posteroanterior view of the left forearm (a), lateral view of the left forearm (b), posteroanterior view of the left elbow joint (c), lateral view of the left elbow joint (d) 
wire (K-wire) (Fig. 2). The extremity was immobilized in a long arm plaster slab with the elbow in $90^{\circ}$ flexion and the forearm in the neutral position for 4 weeks. Extension exercises of the elbow joint were started with a limited motion brace. After 8 weeks, the K-wire was removed from the DRUJ, and pronation and supination exercises were then commenced. After 12 months, the patient had no pain or clinical evidence of instability (Fig. 3). The range of motion was $0-135^{\circ}$ at the elbow, $70^{\circ}$ extension and $80^{\circ}$ flexion at the wrist, and $80^{\circ}$ supination and $80^{\circ}$ pronation at the forearm (Fig. 4).

\section{Discussion and conclusions}

Association of the Galeazzi fracture with dislocation of the elbow would result in dislocation of the DRUJ and ulnohumeral joint. The ulna loses the protection of the ligament structure and exhibits a floating condition. This complex injury can be considered a "floating ulna" injury, which differs from the Essex-Lopresti injury, CrissCross injury, floating forearm, and floating radius injury of the forearm [12-16].

The mechanism responsible for the "floating ulna" injury in the present case can be considered as due to a transmission of axial forces starting from the outstretched hand combined with extreme pronation of the forearm to full elbow extension. The forceful axial loading from the impact with the ground could have caused the dislocation of the DRUJ, resulting in the radius fractures. Collapse of the radial column would result in transmission of the continuing force through the intact ulna and interosseous membrane of the forearm. The transmitted axial force levers the ulna out of trochlear articulation, causing dislocation of the ulnohumeral joint.
Of the publications, only 7 cases of "floating ulna" injury were strictly screened out [4-10] (Table 1), comprising five male and two female patients. The average age of the 7 patients was 34 years old ( $26-58$ years). According to the accident described in the previous studies (Table 1), falling from a height of 1-2 $\mathrm{m}$ was the most likely cause of "floating ulna" injury [4-10]. High-energy trauma in most cases is another cause of the "floating ulna" injury. Nanno et al. [4] reported a case of Galeazzi fractures associated with dislocation of the right elbow and fracture of the right scaphoid caused by a motorbike accident. Ng and Rose [5] described a case caused by car accident combining a Galeazzi fracture, elbow dislocation and fracture of the scaphoid and ulnar styloid. The authors believed that posterior elbow subluxation associated with radial head and coronoid fracture (terrible triad variant) was a result of varus posteromedial rotation force. Sarup and Bryant [6] reported an unusual case of Galeazzi fracture combined with elbow dislocation and an additional ipsilateral humeral shaft fracture resulting from a fall down a flight of stairs. The direction of ulnar dislocation was unclear because the lateral radiograph was not shown. Adanir et al. [7] reported a case that was also a result of a relatively high-energy sports trauma that caused an open Galeazzi fracture and ipsilateral elbow dislocation. The patient in this report likely undergone a motorcycle accident injury with a similar mechanism to that described by Rajeev et al. [8]. However, that case was associated with subacute posterior dislocation of the elbow that was identified five weeks after open reduction internal fixation of the radial shaft fracture. Nevertheless, only one case was caused by a low-energy trauma that sustained a complex injury,

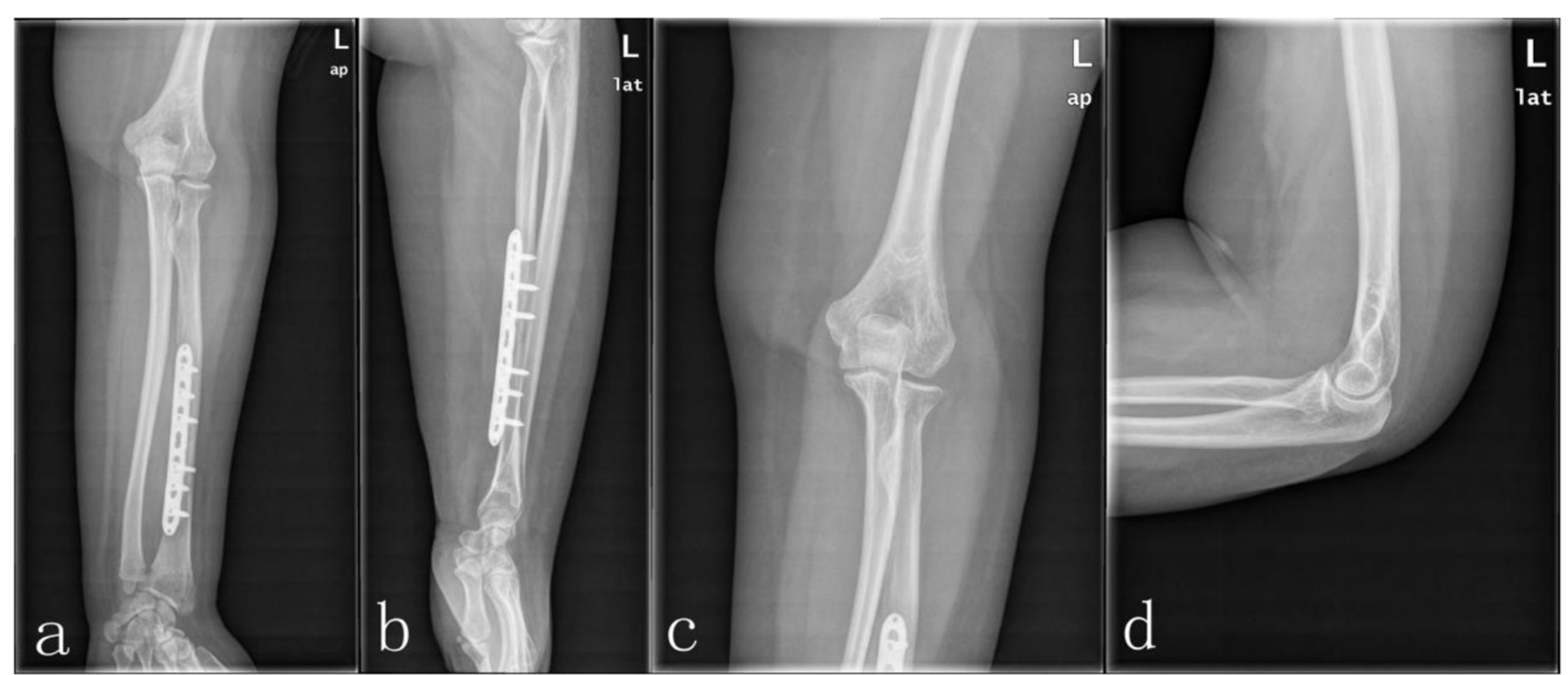

Fig. 3 The $X$-rays of the final follow-up at 12 month 


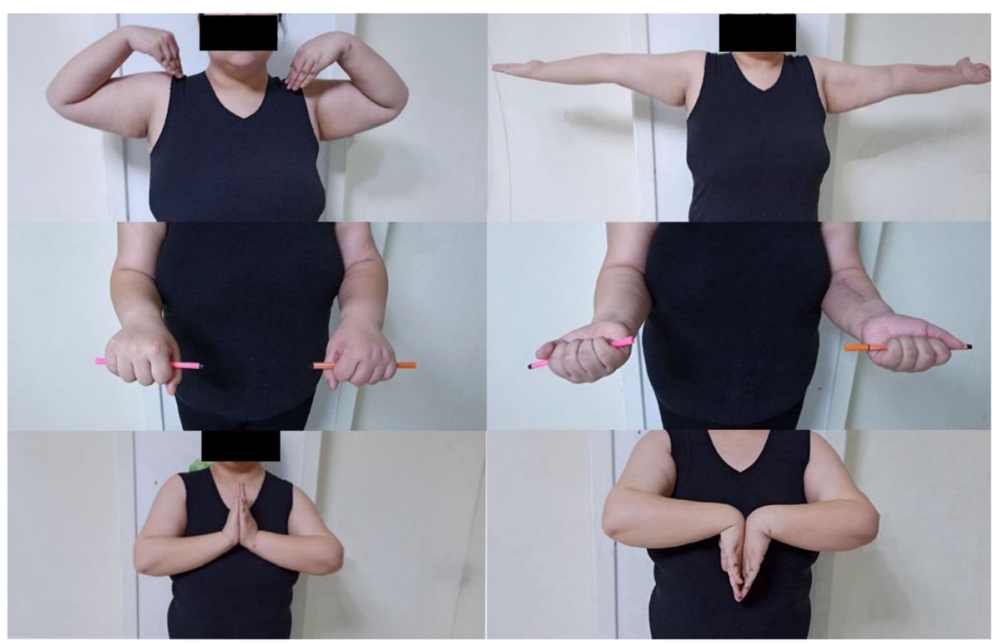

Fig. 4 The range of motion at the 12 month follow-up

with the body weight of the patient acting as a driving force resulting in Galeazzi fracture, elbow dislocation, and radial head fracture [9]. Regarding the Galeazzi fracture in adults, a much greater number of reported ulna-dorsal type than apex- palmar type fractures has been reported [17]. However, according to previous publications (Table 1), the apex- palmar type combined with elbow dislocation occurred in 4 cases, and the apex-palmar type Galeazzi fracture might be more likely than apex-dorsal type to cause "floating ulna" injury. All the patients had successful outcomes, which were achieved by addressing each component of the complex injury individually.

According to the literatures and the levers from forceful transmission of axial force starting from the wrist and extending to the elbow, a classification of four types of "floating ulna" injuries was recommended: Type I: Ipsilateral Galeazzi fracture and instability of the elbow; Type II: Ipsilateral Galeazzi fracture and elbow dislocation; Type III: Ipsilateral Galeazzi fracture, elbow dislocation, and forearm fractures, in which the forearm fracture include only those fractures around the elbow

Table 1 Previously published studies with "floating ulna" injury in adults

\begin{tabular}{|c|c|c|c|c|c|c|c|c|c|}
\hline \multirow[t]{2}{*}{ Author } & \multirow[t]{2}{*}{ Year } & \multirow{2}{*}{$\begin{array}{l}\text { Age/ } \\
\text { Gender }\end{array}$} & \multirow[t]{2}{*}{ Mechanism } & \multicolumn{3}{|c|}{ Injury description } & \multicolumn{3}{|l|}{ Treatment } \\
\hline & & & & $\begin{array}{l}\text { Type of } \\
\text { Galeazzi } \\
\text { fracture }\end{array}$ & $\begin{array}{l}\text { Elbow } \\
\text { dislocation }\end{array}$ & $\begin{array}{l}\text { Associated } \\
\text { injury }\end{array}$ & Galeazzi fracture & $\begin{array}{l}\text { Elbow } \\
\text { dislocation }\end{array}$ & Associated injury \\
\hline $\begin{array}{l}\text { Adanir } \\
\text { et al. [7] }\end{array}$ & 2016 & $26 / M$ & $\begin{array}{l}\text { Fall while } \\
\text { running }\end{array}$ & $\begin{array}{l}\text { Apex volar } \\
\text { type }\end{array}$ & $\begin{array}{l}\text { Posterolateral } \\
\text { dislocation }\end{array}$ & - & $\begin{array}{l}\text { Radial plating and } \\
\text { DRUJ pinning }\end{array}$ & $\begin{array}{l}\text { Closed } \\
\text { reduction }\end{array}$ & - \\
\hline $\begin{array}{l}\text { Asadollahi } \\
\text { et al. [9] }\end{array}$ & 2013 & $58 / F$ & $\begin{array}{l}\text { Fall while } \\
\text { running }\end{array}$ & $\begin{array}{l}\text { Apex dorsal } \\
\text { type }\end{array}$ & $\begin{array}{l}\text { Posterolateral } \\
\text { dislocation }\end{array}$ & $\begin{array}{l}\text { Radial head } \\
\text { fracture }\end{array}$ & $\begin{array}{l}\text { Radial plating and } \\
\text { DRUJ pinning }\end{array}$ & $\begin{array}{l}\text { Closed } \\
\text { reduction }\end{array}$ & $\begin{array}{l}\text { Conservative } \\
\text { treatment }\end{array}$ \\
\hline $\begin{array}{l}\text { Rajeev } \\
\text { et al. [8] }\end{array}$ & 2011 & $26 / M$ & $\begin{array}{l}\text { Motorcycle } \\
\text { accident }\end{array}$ & $\begin{array}{l}\text { Apex dorsal } \\
\text { type }\end{array}$ & $\begin{array}{l}\text { Subacute } \\
\text { Posterior } \\
\text { dislocation }\end{array}$ & - & Radial plating & $\begin{array}{l}\text { Open } \\
\text { reduction }\end{array}$ & - \\
\hline $\begin{array}{l}\text { Nanno } \\
\text { et al. [4] }\end{array}$ & 2011 & $32 / \mathrm{M}$ & $\begin{array}{l}\text { Motorcycle } \\
\text { accident }\end{array}$ & $\begin{array}{l}\text { Apex volar } \\
\text { type }\end{array}$ & $\begin{array}{l}\text { Posterior } \\
\text { dislocation }\end{array}$ & $\begin{array}{l}\text { Scaphoid and } \\
\text { ulnar styloid } \\
\text { fracture }\end{array}$ & $\begin{array}{l}\text { Radial plating and } \\
\text { tensionband of ulna } \\
\text { fracture }\end{array}$ & $\begin{array}{l}\text { Closed } \\
\text { reduction }\end{array}$ & $\begin{array}{l}\text { Herbert screw } \\
\text { internal fixation }\end{array}$ \\
\hline $\begin{array}{l}\mathrm{Ng} \text { and } \\
\text { Rose [5] }\end{array}$ & 2010 & $27 / M$ & $\begin{array}{l}\text { Car } \\
\text { accident }\end{array}$ & $\begin{array}{l}\text { Apex volar } \\
\text { type }\end{array}$ & $\begin{array}{l}\text { Posteromedial } \\
\text { dislocation }\end{array}$ & $\begin{array}{l}\text { Radial head and } \\
\text { coronoid fracture }\end{array}$ & $\begin{array}{l}\text { Radial plating and } \\
\text { DRUJ pinning }\end{array}$ & $\begin{array}{l}\text { Open } \\
\text { reduction }\end{array}$ & $\begin{array}{l}\text { Free bone debrided } \\
\text { and suture anchor } \\
\text { fixation }\end{array}$ \\
\hline $\begin{array}{l}\text { Shiboi } \\
\text { et al. [10] }\end{array}$ & 2005 & $34 / \mathrm{M}$ & $\begin{array}{l}\text { Fall from } 2 \\
\mathrm{~m} \text { height }\end{array}$ & $\begin{array}{l}\text { Apex volar } \\
\text { type }\end{array}$ & $\begin{array}{l}\text { Posteromedial } \\
\text { dislocation }\end{array}$ & - & Radial plating & $\begin{array}{l}\text { Closed } \\
\text { reduction }\end{array}$ & - \\
\hline $\begin{array}{l}\text { Sarup and } \\
\text { Bryant [6] }\end{array}$ & 1997 & $35 / F$ & $\begin{array}{l}\text { Fall from } \\
\text { flight of } \\
\text { stairs }\end{array}$ & unknow & $\begin{array}{l}\text { Posterolateral } \\
\text { dislocation }\end{array}$ & $\begin{array}{l}\text { Humeral shaft } \\
\text { and ulnar styloid } \\
\text { fracture }\end{array}$ & Radial plating & $\begin{array}{l}\text { Closed } \\
\text { reduction }\end{array}$ & $\begin{array}{l}\text { Humeral } \\
\text { intramedullary } \\
\text { fixation }\end{array}$ \\
\hline
\end{tabular}




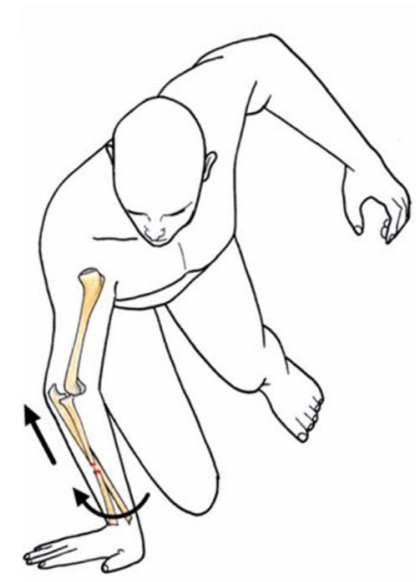

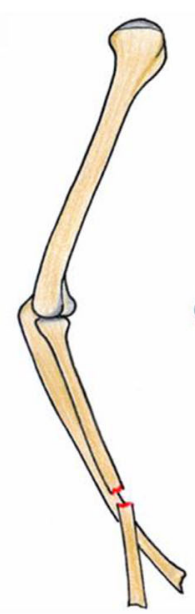

Type I

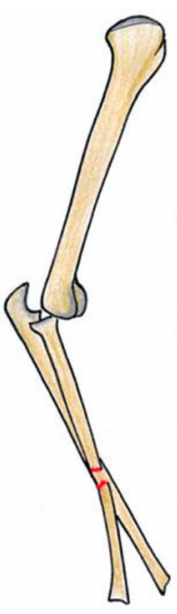

Type II

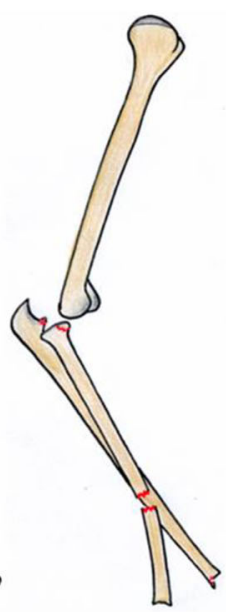

Type III

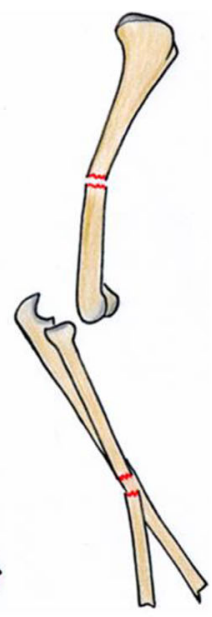

Type IV

Fig. 5 The "floating ulna" injure classified into four types, take apex-palmar type Galeazzi fracture for example

(radial head and coronoid fracture) or around the wrist (scaphoid and ulnar styloid fracture), and the shaft fracture of the ulna and proximal and medial fracture of the radius are excluded; Type IV: Ipsilateral Galeazzi fracture, elbow dislocation, and fracture of the humerus (Fig. 5).

This case of "floating ulna" injury was likely caused by significant amount of deforming force and the unique position of upper limb when the patient fell from a height of 1-2 $\mathrm{m}$ in high-energy trauma.

\section{Abbreviations}

DRUJ: The distal radioulnar joint; CT: Computerized tomography; Kwire: Kirchner wire

\section{Acknowledgements}

Not applicable.

\section{Authors' contributions}

Dr. TH. and Dr. LGZ. proform the operation and drafted the manuscript. Dr. SS. participated in the design of the study and data collection. Dr. XW. performed the literature search. Dr. TH. conceived of the study, and participated in its design and coordination and helped to draft the manuscript. All authors read and approved the final manuscript.

\section{Funding}

This research received no specifific grant from any funding agency in the public, commercial, or not-for-profifit sectors.

\section{Availability of data and materials}

Data sharing not applicable to this article as no datasets were generated or analysed during the current study.

\section{Ethics approval and consent to participate}

This article does not contain any studies with animal subjects. All procedures were in accordance with the ethical standards of the responsible committee on human experimentation (institutional and national) and with the Helsinki Declaration of 1975, as revised in 2008. Informed consent was obtained from the patient for being included in the study.

\section{Consent for publication}

Written informed consent for publication of their clinical details and clinical images was obtained from the patient.

\section{Competing interests}

The authors declare that they have no competing interests.

Received: 1 October 2020 Accepted: 14 December 2020

Published online: 06 January 2021

\section{References}

1. Giannoulis FS, Sotereanos DG. Galeazzi fractures and dislocations. Hand Clin. 2007;23(2):153.

2. Atesok Kl, Jupiter JB, Weiss AP. Galeazzi fracture. J Am Acad Orthop Surg. 2011:19(10):623-33.

3. Hobgood ER, Khan SO, Field LD. Acute dislocations of the adult elbow. Hand Clinics. 2008:24:1-7.

4. Nanno M, Sawaizumi T, Takai S. Case of bilateral Galeazzi fractures associated with dislocation of the right elbow. J Nippon Med School. 2011; 78:384-7.

5. Ng VY, Rose S. Combined elbow fracture-dislocation and Galeazzi fracture in an adult: a case report and review of the literature. Curr Orthop Pract. 2010; 21:330-3.

6. Sarup S, Bryant PA. Ipsilateral humeral shaft and Galeazzi fractures with a posterolateral dislocation of the elbow: a variant of the "floating dislocated elbow". J Trauma. 1997:43:349-52.

7. Adanır O, Yüksel S, Beytemur O, Güleç MA. Open Galeazzi fracture with ipsilateral elbow dislocation, Eklem Hastalık Cerrahisi. 2016;27(2):113-6.

8. Rajeev A, Senevirathna S, Harrison J. Subacute dislocation of the elbow following Galeazzi fracture-dislocation of the radius: a case report. J Med Case Rep. 2011;5:589.

9. Asadollahi S, Shepherd D, Hau RC. Elbow fracture-dislocation combined with Galeazzi fracture in adult: A case report and literature review. Int I Surg Case Rep. 2013:4:748-52.

10. Shiboi R, Kobayashi M, Watanabe $Y$, Matsushita T. Elbow dislocation combined with ipsilateral Galeazzi fracture. J Orthop Sci. 2005;10:540-2.

11. Ilyas AM. Surgical approaches to the distal radius. Hand (N Y). 2010;6(1):817.

12. Masouros PT, Apergis EP, Babis GC, Pernientakis SS, Igoumenou VG Mavrogenis AF, Nikolaou VS. Essex-Lopresti injuries: an update. EFORT Open Rev. 2019:4(4):143-50.

13. Artiaco S, Fusini F, Colzani G, Massè A, Battiston B. Chronic Essex-Lopresti injury: a systematic review of current treatment options. Int Orthop. 2019; 43(6):1413-20. 
14. Jin $X Y$, Zhao WB, Dong $Y Q$, Huang $Y G$. Simultaneous dislocation of the radial head and distal radio-ulnar joint without fracture in an adult patient: a case report and review of literature. BMC Surg. 2020;20(1):71.

15. Plucknette BF, Rhee PC. An Unusual Variant of a Floating Forearm Injury: A Case Report and Review. Hand (N Y). 2018;13(6):NP32-8.

16. Jupiter JB, Kour AK, Richards RR, Nathan J, Meinhard B. The floating radius in bipolar fracture-dislocations of the forearm. J Orthop Trauma. 1994;8(2):99106.

17. Macule Beneyto F, Arandes Renu JM, Ferreres Claramunt A, Ramon SR Treatment of Galeazzi fracture-dislocations. J Trauma. 1994;36:352-5.

\section{Publisher's Note}

Springer Nature remains neutral with regard to jurisdictional claims in published maps and institutional affiliations.

Ready to submit your research? Choose BMC and benefit from:

- fast, convenient online submission

- thorough peer review by experienced researchers in your field

- rapid publication on acceptance

- support for research data, including large and complex data types

- gold Open Access which fosters wider collaboration and increased citations

- maximum visibility for your research: over $100 \mathrm{M}$ website views per year

At BMC, research is always in progress.

Learn more biomedcentral.com/submissions 